\title{
AKAR PENDIDIKAN KEWARGANEGARAAN DI PESANTREN
}

\author{
Ahmad Baso \\ Komnas HAM RI \\ Jalan Latuharhari No. 4 B Kelurahan Menteng Jakarta Pusat 10310 \\ Email:ahmadbaso@yahoo.com
}

\begin{abstract}
ABSTRAK
Tulisan ini bertujuan menggambarkan sisi lain dari pesantren yang selama ini dinilai sebagai lembaga pendidikan Islam yang kolot, tradisional, dan terbelakang. Metode penelitian yang digunakan adalah metode historis. Naskah-naskah primer tentang kepesantrenan yang justru bertebaran di toko buku loakan dianalisis, diinterpretasi, dan di-crosscheck dengan tulisan para orientalis yang selalu dipajang di toko buku beratmosfir supermal dan selalu dianggap benar oleh para peneliti pendidikan Islam. Hasil temuan menunjukkan bahwa di pesantren, santri diajari demokratis, toleran kepada sesama, menghargai perbedaan (pluralisme), dan kosmopolit terhadap ilmu pengetahuan. Sikap-sikap tersebut ternyata merupakan fundamen ideologi bangsa kita. Berarti, memahami pesantren sebetulnya memahami bagaimana cara mencintai Bangsa dan Negara Indonesia. Dengan demikian, pendidikan pesantren adalah pendidikan Islam yang bermaksud menanamkan dan mencintai bangsanya sendiri.
\end{abstract}

Kata Kunci: Pesantren, Santri, Bangsa

\section{ABSTRACT}

This paper aims to describe the other side of the Pesantren that has been stereotyped as a conservative, traditional, and old fashioned islamic education institution. The research used the historical method. Particularly, it attempted to analyze and interprete as well as crosscheck between the primary pesantren texts gained from bookstore flea market and the writings of Orientalists' displayed in the bookstore in Supermall which is always regarded to be more valid by the researchers of Islamic education. The findings showed that in pesantren, students were taught to be democratic, tolerant to others, respect differences (pluralism), and cosmopolitan to science. Moreover, those attitudes proved to be a fundamental ideology of our nation. In other words, understanding Pesantren actually understands how to love the nation and the State of Indonesia. Thus, education in pesantren refers to education of Islamic boarding schools intended to inculcate and love their own people.

Keywords: Pesantren, Santri, Nation 


\section{PENDAHULUAN}

"Anak ambtenaren, senang pakaian, ideologis kosong ..." Itu ejekan kaum santri di Banten tahun 1940-an kepada anak priai sekolahan yang masuk tentara Peta di masa pendudukan Jepang (Williams dalam Kahin (editor), 1985: 78). Ejekan ini mencerminkan sikap kolektif anti kolonial orang pesantren. Mereka percaya bahwa orang Indonesia yang dikader di sekolah-sekolah Belanda tidak akan bisa dipercaya memimpin bangsa ini. Dalam otobiografi seorang Bupati Serang di masa kolonial disebutkan bahwa kalangan santri, selain belajar Tashriffan dan Matn al-Ajuruimiyah tentang gramatika Bahasa Arab, juga belajar tentang hidup sederhana, disiplin, patuh kepada guru, kebersamaan, sikap anti pemerintah Belanda, serta kebencian terhadap para pegawai atau ambtenar-nya (Djajadiningrat, 1996: 25-28 dan 1936: 437-438). Masa itu sudah menunjukkan bahwa orang pesantren adalah orang yang paling siap dalam menghadapi kolonialisme dan bukan justru meminta-minta atau bergelatungan di ketiak para penguasa kolonial sambil menerima imbalan ribuan gulden [1972] (Anderson, 2006).

Soetomo dan Dewantara pernah membela pesantren di tengah serangan para pendukung sekolah kolonial. Pendukung sekolah modern-kolonial menyebut pesantren sebagai sekolah feodal, tradisional dan tidak sesuai dengan perkembangan zaman. Mereka, meski pernah mengenyam sekolah ala Barat, justru membela hakikat pengajaran pesantren (Mihardja-pengumpul, 1986). Soetomo menganggap pesantren sebagai wahana penggemblengan rakyat dan pembangunan mental populisme-kebangsaan sedangkan sekolah kolonial hanya menghasilkan pegawai, ditujukan untuk mengasah otak saja, mencipta manusia 'egoistik' dan saling bersaing untuk mendapat secupak nasi. Menurutnya, pendidikan modern-kolonial telah mengasingkan anak Bangsa Indonesia dari masyarakatnya dan tidak peduli dengan bangsanya sendiri. Untuk mengubah keadaan menyedihkan ini maka sekolah rakyat harus demokratis sebagaimana dikehendaki Islam. Sang guru harus menjadi kiai di tempatnya dan mengubah jiwa egoistik menjadi jiwa yang bersedia berkorban bagi kepentingan rakyat (Van Der Veur, 1984: 35-36).

Dewantara menyebut pesantren sebagai tipe ideal pendidikan nasionalis bahkan karakter kebangsaan Taman Siswa berhubungan dengan dunia pesantren (Tsuchiya, 1992: 153-154). Para aktivis pesantren adalah aktivis Taman Siswa. Di Jawa Timur yang berbasis NU/pesantren, Taman Siswa lebih banyak diterima dibandingkan dengan di Jawa Tengah dan Yogyakarta sebagai basis sekolah Muhammadiyah. Beberapa aktivis NU di Medan era 1930-an yang menceritakan kembali pandangan keagamaan-sosial-politik ibu, ayah, dan pamannya menunjukkan bahwa orang tua mereka adalah aktivis NU Medan. Mereka berguru kepada tokoh NU Medan, Syekh Muhammad Zen (Joesoef, 2003). Tokoh/ulama/pengasuh Dayah Tanjungan Samalanga Aceh, Samalanga (wafat 1968), mendirikan Perguruan Taman Siswa di Jeunien, Aceh pada tahun 1933. Hubungan antara kehidupan dayah dengan rakyat dipupuk dalam sekolah 
ini. Dalam penggerebekan terhadap para pelaku pemberontakan Belanda di tahun 1920-an, Samalanga sempat lolos. Beliau kemudian berangkat ke Mekah menuntut ilmu pada 1926. Sekembalinya ke Tanah Air, ia langsung membentuk wadah pengkaderan nasionalisme melalui pendidikan kebangsaan, mengasuh dayah/pesantren, mendirikan madrasah dan Sekolah Taman Siswa (Hasjmy, 1997: 55-66).

Saat ini adalah saat yang penuh dengan proses pemiskinan ideologi bangsa, krisis moral, korupsi, krisis keteladanan dan hedonisme. Tanah, aset-aset bangsa, dan sumber alam bangsa Indonesia dengan gampang dijual kepada bangsa asing. Pemimpin tidak lagi bisa melindungi rakyatnya. TKI/TKW-nya dihukum pancung. Para wakil rakyat dari pusat ke daerah sibuk memperkaya diri dan mencari proyek agar terpilih lima tahun berikutnya. Pancasila sudah dilupakan karena mahasiswa sibuk dengan civil society, demokrasi, dan reformasi. Anak sekolah lebih mendalami Upin-Ipin daripada Ideologi Negara Pancasila dan Pembukaan UUD 1945. Lagu Indonesia Raya kalah nyaring dengan lagu Noah. Isu pluralisme, minoritas, kebebasan beragama, terorisme dan kasus Ahmadiyah, justru digunakan untuk mengoyak dasar-dasar kebersamaan kebangsaan dan persatuan Indonesia. Maka ada benarnya, Muktamar NU di Makassar 2010, PBNU menggelorakan semangat kembali ke pesantren.

\section{PEMBAHASAN}

\section{Kembali ke Pesantren, Kembali kepada Fundamen Ideologi Bangsa}

Ciri khas pesantren adalah penghargaan terhadap para leluhur/ulama/ pendahulu/pahlawan yang berjasa/berjuang untuk bangsa ini. Pesantren membantu anak bangsa ini memelihara segenap memori kolektif masa lalu tentang kejayaan/kejuangan/pengalaman/pengorbanan berhadapan dengan bangsa asing demi terwujudnya bangsa dan tanah air Indonesia. Mekanisme untuk itu dilakukan dengan memelihara sejumlah tradisi, ritual, praktik keagamaan, kesenian dan kebudayaan yang menghubungkan satu generasi ke generasi berikutnya, dari satu komunitas ke komunitas lainnya, sehingga solidaritas berbangsa, persatuan dan kebersamaan di antara komponen bangsa ini tetap terjaga.

Tradisi di atas dipelihara oleh pesantren karena kedekatannya dengan penghormatan terhadap tanah, air, laut, hutan, gunung dan sumber daya alam yang dimiliki nusantara. Keberadaan makam keramat di dekat mata air, hutan dan gunung, dirawat oleh orang pesantren untuk kepentingan menjaga kesinambungan sumber air bagi kehidupan manusia. Tempat tertentu yang dianggap keramat ("angker", “dipenuhi”) dipelihara oleh pesantren karena ada keterkaitan historis dengan sejumlah jejak/petilasan tokoh/ulama/wali/ pendakwah dan pembuka/kehadiran desa/pesantren awal. Letak tempat keramat menyebabkan segenap kekayaan alam bisa menjadi bagian dari ketahanan kultural-ekonomi masyarakat, tanpa diliberalisasi untuk kepentingan pemodal, 
yang berdampak pada pemiskinan masyarakat sekitar. Hefner menunjukkan bahwa ada keterkaitan antara proyek pembangunan Orde Baru tentang pembukaan lahan industri dengan upaya mematikan kepercayaan masyarakat terhadap tempat keramat dengan cara memelihara kelompok Islam puritanmodernis-reformis yang mendakwahkan kepada masyarakat tentang praktik yang dianggap syirik, takhayyul dan khurâfat, sehingga kekayaan alam tersebut dengan mudah menjadi lahan eksploitasi kapitalis. Upaya ini diperhalus dengan "isu lingkungan hidup", pemanasan global "go green" (Hefner, 1987: 533-554).

Pesantren adalah wadah kaderisasi anak bangsa untuk menjadi pemimpin di masa depan. Calon pemimpin bangsa dikader di pesantren untuk menjadi pelindung, penjaga, dan pemelihara tradisi kebudayaan bangsa ini. Diponegoro, ketika dikader di Pesantren Mlangi Yogyakarta yang diasuh oleh Taftajani diajari bukan hanya pelajaran dasar keagamaan, tapi juga warisan peradaban leluhur bangsa ini, dari Sriwijaya hingga Majapahit, dari Pararaton, Tajussalatin, Serat Ambiya hingga Kitab Tohfah (Carey, Peter, 1986: 59-137). Mereka dikader untuk mengerti keadaan rakyat jelata. Mereka diajarkan untuk bisa mengikuti cara hidup ulama yang dekat dengan penduduk. Diponegoro menuturkan bahwa untuk meniru yang dilakukan ulama, kami kerapkali pergi ke Pasar Gede, Imogiri (Jimatan), Guwa Langse dan Selarong. Saat ke Pasar Gede dan Imogiri, kami biasa berjalan kaki. Saat ke Guwa Langse dan Selarong, kami naik kuda dengan banyak pengiring (rakyat). Di kedua tempat ini, kami sering menolong petani menuai dan menanam padi (Kartodirdjo, Poesponegoro dan Notosusanto, 1977: 169).

Kaum menak dan anak ningrat di Priangan dan Banten dikader di pesantren untuk bisa mengenal tradisi bangsanya yang bbinneka tunggal ika. Mereka dikader di pesantren untuk menghayati kehidupan rakyat (Lubis, 2004 dan, 1998). Wiranatakusumah mengajarkan Soekarno bergaul dengan ulama (Kiai Sukanegara) di Priangan (Soeharto, 1982: 14; dan Navis, 1989). Justru kehadiran penjajah dan sarjana kolonial lain yang membuat mereka terasing dari pesantren. Hurgronje mengader anak keluarga Djajadiningrat, Hasan Mustafa. Holle mengader Muhammad Moesa dari Limbangan-Garut. Kompeni mengader anak Kraton Surakarta dan Yogyakarta serta sekian anak ningrat Nusantara sebagai imbangan terhadap "Islam pesantren". Dewantara mensinyalir bahwa ini salah satu skema divide-et-impera penjajah untuk memecah belah potensi persatuan bangsa Indonesia. Nusantara dipecah-pecah secara sistematis. Daerah satu dijauhkan dari daerah lain. Belanda berupaya terus "memurnikan" kebudayaan daerah setempat. Untuk itu didirikan Java-Institunt, Batak-Instituut, dan Bali Institunt (Dewantara, 1994: 98).

Orang pesantren mengajarkan anak bangsa tentang persatuan bangsa. Zuhri menyebut bahwa tradisi kitab kuning merupakan perekat Islam Nusantara/perekat bangsa (Zuhri, 1987). Salah satu instrumennya adalah tradisi santri kelana. Mereka membentuk jaringan kebangsaan. Tetapi ini pula yang 
menjadi obyek penjinakan yang dilakukan penjajah. Mereka memotong pergerakan santri kelana.

Sejak masa Mataram, Perjanjian Gyanti 1755, hingga Perang Jawa, dan perang anti kolonial, orang pesantren menjadi aktor perlawanan, dengan tujuan persatuan dan kesatuan bangsa. Ketika muncul gerakan pemberontakan kemerdekaan, ulama dan komunitas pesantren tampil membela NKRI dari rongrongan kaum separatis. Mereka menyebut pemberontakan itu bughât madzmûmah (tercela). Rimba dengan ulama Aceh lain yang berhaluan Aswaja, Kalee (guru Rimba sendiri), al-Khalidy, menyebut bahwa pemberontakan DI/TII itu sebagai madzmûmah. Menurut mereka, orang yang terlibat dalam pemberontakan tersebut dianggap menyalahi hukum Allah dan Rasul-Nya. Sebab, mereka memberontak terhadap pemerintahan republik yang sah dan pemimpinnya, Soekarno, juga seorang Muslim. Pemberontakan tersebut dianggap mengganggu kemaslahatan bernegara. Ini berseberangan dengan konsep bahwa (politik) siyâsah adalah daya helah/strategi untuk mencapai kemaslahatan negara (Rimba, 1980; Tim Penulis IAIN Ar-Raniry, 2004; Hasjmi, 1997).

Saat ini, banyak yang mentolerir aktor yang dulu memberontak NKRI. Majalah Tempo sempat memasukkan tokoh Islam awal kemerdekaan (Wahid Hasyim) dengan empat tokoh mantan pemberontak (Natsir, Kartosuwiryo, dan Daud Beureueh). Ada ironi dalam logika majalah ini ketika menempatkan pembela dengan perongrong NKRI. Rupanya, banyak pemimpin bangsa ini yang sudah mengalami amnesia kolektif terhadap dunia pesantren.

\section{Pendidikan Kebangsaan Pesantren}

Pesantren adalah pusat pemeliharaan berbagai tradisi keilmuan yang diproduksi anak bangsa mulai tradisi kesastraan Nusantara hingga tradisi ilmu sosial pesantren. Tradisi kesastraan yang dipelihara pesantren ditulis menggunakan huruf Arab pegon, dengan beragam bahasa Nusantara. Kandungannya beragam, mulai cerita roman, sejarah dan realitas sosial, hingga cerita yang dipenuhi tema moralitas dan kepahlawanan. Meskipun beragam, tetapi mampu melukiskan kenyataan sosial, realis, melibatkan tingkah laku, norma sosial dan budaya masyarakat. Tampilnya pesantren sebagai tempat persemaian tradisi kesusastraan menunjukkan bahwa pesantren bukan hanya tempat belajar, tetapi juga lembaga kehidupan dan kebudayaan. Pada abad ke-1718, pesantren menjadi tempat para pujangga menghasilkan karya sastra. Pujangga kraton, seperti Yasadipura I, Yasadipura II, dan Ranggawarsita, adalah santri pesantren yang tekun mengembangkan karya sastra dalam bentuk kakawin, serat dan babad. Sumber inspirasi mereka bukan hanya kitab kuning, melainkan juga pengalaman sejarah bangsa sendiri sebagaimana dialami oleh kerajaan Hindu, Budha, dan zaman Wali Sanga. Yasadipura I (wafat 1801) adalah pujangga istana Kraton Surakarta yang pernah nyantri di sebuah pesantren di Kedu-Bagelen. Dalam Serat Cabolek, Yasadipura menggambarkan seorang ulama dari Kudus, 
yang menunjukkan keahliannya dalam membaca dan menafsirkan naskah Jawa Kuno di hadapan para priai Kraton Surakarta. Cakupan bacaannya pun luas, mulai dari naskah Jawa Kuno, Serat Dewaruci hingga Suluk Malang Sumirang.

Karya pesantren berkisar pada cerita rakyat Nusantara, Timur Tengah dan India yang sudah disesuaikan dengan kebutuhan lokal Islam Nusantara. Tjarita Ibrahim (1859), Tjarita Nurulqamar, dan Hibat (1881) ditulis dalam bahasa Sunda dengan aksara Arab dalam bentuk puisi. Mohammad Moesa menulis Wawacan Panji Wulung yang bahannya diperoleh dari pesantren di sekitar Priangan. Karya Hassan Musthafa (1852-1930) banyak berbasis pada tradisi pesantren. Ia mengintegrasikan khazanah fiqih dan sufisme pesantren ke dalam adat Sunda dalam bentuk simbol pemaknaan yang akrab. Pada karya modern yang sudah menggunakan huruf Latin, ada "Pahlawan ti Pasantren" (Pahlawan dari Pesantren), karya Ki Umbara (1914-2004) dan Abdoerrachman (1918-1971). Ini adalah roman berbahasa Sunda yang menceritakan perjuangan santri menghadapi kolonialisme Belanda.

Dalam bahasa Jawa, Serat Jatiswara, Serat Centhini, dan Serat Cabolek adalah contoh karya pesantren dari pesisir utara Jawa. Ini adalah teks sastra kaum santri sejak abad ke-17-18, yang diproduksi dan beredar di kalangan santri pesisir, yang kemudian dibakukan menjadi "milik kraton" oleh Yasadipura II pada pertengahan abad ke-19. Kisah perjalanan kaum santri pengembara (santri lelana) menuntut ilmu di berbagai pondok dan tempat keramat mendominasi karya ini. Kekayaan tradisi keilmuan pesantren juga ditunjukan dalam Hikayat Pocut Muhammad dan Hikayat Indrapura dalam beberapa versi lokalnya. Serat Jatiswara dalam versi yang beredar dari abad ke-18 di pesisir utara Jawa dan Lombok, menunjukkan satu fungsi sosial bagi komunitasnya. Para pemilik manuskrip kesastraan ini yang kebanyakan berpendidikan pesantren, menegaskan kepemilikannya dengan menambahkan kolofon, catatan dan tanda tangan pada dua halaman terakhir. Di daerah pesisir dan dalam suasana pesantren yang relatif demokratis, pembuatan buku dan penyalinan teks nampaknya lebih merupakan urusan orang kecil dan masyarakat bawah, daripada dalam kalangan kraton Jawa Tengah. Dalam lingkungan kraton, manuskrip hanya menjadi milik sebagian orang.

Fungsi sosial sastra pesantren juga ditunjukan dari cara kaum santri melakukan penggubahan, tulis-ulang, penambahan dan penyisipan, untuk disesuaikan dengan cita-cita sosial-keagamaan kaum pesantren, seperti dalam Hikayat Malem Diwa. Hikayat ini berbahasa Melayu ditulis dengan huruf Arab pegon yang diwarnai kosmologi Hindu. Dalam naskah tersebut disisipkan satu predikat "guru ngaji di meunasah (semacam langgar di Aceh)" kepada tokoh protagonis. Walaupun sangat kecil, sisipan tersebut mengandung arti yang signifikan. Keseluruhan konstruksi cerita berubah total, karena pesantren memainkan peran baru dalam memberi spirit dan corak kesastraan lama meskipun sang tokoh tidak disebut terang-terangan memeluk Islam. Dalam cerita epos I La Galigo (Bugis), dengan tokoh Sawerigading, disisipkan satu versi 
cerita bahwa Sawerigading nyantri ke Mekah, naik haji, bertemu dengan Nabi Muhammad SAW, dan kembali ke kampungnya mendirikan masigi (mesjid plus pondok). Versi Sawerigading santri baik lisan maupun tulisan masih terpelihara di beberapa pesantren Bugis-Makasar.

Sastra pesantren mengintegrasikan tradisi ke-syuyukkhiyah-an (jejer pandita) sebagai bagian penting dari lakonnya. Penulisan kembali Hikayat Iskandar Dzulqarnain dari Timur Tengah ke dalam versi bahasa Nusantara, Melayu, Jawa, dan bahasa lokal Nusantara lain, memasukkan figur Nabi Khaidir sebagai guru. Ia membimbing, mengarahkan, dan membawa kesuksesan bagi Iskandar yang taat kepada gurunya. Dengan penekanan pada relasi guru-santri ini, misalnya dalam Sejarah Melayu, Hikayat Aceh, dan Tambo Minangkabau, muncul sosok ulama fiqih Syafi'i asal Minangkabau dari akhir abad ke-18.

Sastra pesantren mengungkapkan diri dalam karya etnografis-kesejarahan, seperti dalam Poerwa Tjarita Bali (1875), ditulis dalam bahasa Jawa, oleh santri di Pondok Sepanjang, Malang, bernama Sasrawijaya, asal Yogyakarta. Pengetahuan tentang kota, adat-istiadat pembesar dan orang kebanyakan yang tinggal di desa ini kemudian dituangkan sebagai bagian dari kegiatan bersastra (maguru ing sastra) orang pesantren. Sastra pesantren berkontribusi dalam memperkaya bahasa Nusantara dengan khazanah kosa-kata dan peristilahan berkosmologi pesantren. Kekayaan tersebut membantu penerjemahan karya sastra dari luar. Penerjemah Tionghoa misalnya menggunakan kosa-kata "santri", "ngaji", "koran", dan "langgar", untuk menerjemahkan satu karya sastra klasik Cina Daratan, Serat Ang Dok, ke dalam bahasa Jawa dari abad ke-19 hingga pada awal abad ke-20. Perhatikan bait terakhir Boekoe Sair Tiong Hwa Hwe Kwan Koetika Boekanja Passar Derma (1905), campuran bahasa Melayu, Hokian, dan bahasa khas pesantren: "Sekalian Hwe Kwan poenja alamat/ Terpandang Kwi-khi sebagai djimat/ Nabi Kong Hoe-tjoe jang kita hormat/ Allah poedjiken dengan selamat". Dalam syair ini, terasa kuat pengaruh kesastraan pesantren, bahasa dan pandangan dunia mereka, dalam kesadaran orang Tionghoa yang waktu itu sedang menyambut era kebangkitan kebangsaan mereka.

Kini muncul penulis dan sastrawan asal pesantren yang kuat menonjolkan peradaban dan kejiwaan kaum santri, seperti pada karya Zawawi Imron, Acep Zamzam Noor atau karya novelis Ahmad Tohari. Belakangan muncul Kiai Mustofa Bisri (Gus Mus) yang memperkaya gelanggang puisi Indonesia. Di tengah serbuan sastra Indonesia modern dan kekuatan sastra koran yang didominasi selera estetika sastra perkotaan, karya kaum santri masih marjinal. Karya mereka, terutama penulis muda, baik dari segi tema, alur cerita maupun bahasa masih terbawa arus sastra kanonik. Karya Abidah el-Khaliqiy misalnya, meski menampilkan latar pesantren, tapi masih kuat dorongan ke arah tema utama, individualisasi dan modernisasi.

Kreativitas jadi menurun karena bergesernya di satu sisi fungsi dan peran pesantren, serta situasi yang melingkupinya, di sisi lain menjadi korban diskriminasi oleh standar umum kesusastraan baik standar tema maupun bahasa. 
Maka, pengembangan sastra pesantren setidaknya harus mampu melepaskan diri dari belenggu tersebut. Bagaimana pun, kehadiran sastra pesantren sangat dibutuhkan, seperti yang diperankan di masa lalu, untuk memberikan warna lain pada sastra dan seni budaya Indonesia, yang selama ini cenderung satu warna, satu alur dan satu selera, sehingga nampak monoton. Watak moral-religius sastra pesantren sangat dibutuhkan untuk memberikan semangat baru bagi bangsa ini untuk berpegang teguh pada nilai kebenaran, keadilan, dan kejujuran.

Tradisi ilmu sosial kaum pesantren dimulai dari persepsi tentang karakter umum dari penjajah dan kaki tangannya. Buku kaum santri, mulai dari Syekh Ahmad Chatib Minangkabau yang berjudul Dlaw as-Sirâj, syair dan hikayat Perang Sabil yang ditulis ulama Aceh, hingga buku Zuhri, Guruku Orang dari Pesantren dan Berangkat dari Pesantren, memuat satu bab tentang "Memetakan Wajah-wajah Kaki Tangan Penjajah". Di sana tidak dijumpai teori tentang kebudayaan besar berhadapan dengan tradisi kecil, dikotomi kota-desa, soal buta huruf, soal rakyat miskin, atau tentang mentalitas konservatif dan tradional serta kebudayaan primitif orang desa sebagaimana halnya tradisi ilmu sosial Marxian yang selalu dimulai dari persepsi tentang musuh mereka, kapitalisme. Pergumulan orang pesantren dengan penjajahan, dimulai dari konsolidasi tesisnya, yakni dari tradisi pesantren. Dari tradisi ini, ilmu sosial menginspirasi sebuah aksi dan praksis pada dua lapis, yaitu ideologi dan gerakan, sehingga lahir pesantren bergerak, seperti pengalaman sejumlah pesantren yang dekat dengan pabrik gula di masa kolonial. Pergaulan dekat itu memunculkan ilmu orang pesantren tentang ekonomi-politik, pabrik gula, logika kapitalisme global, perdagangan, ketimpangan dalam ekonomi kolonial, pengalaman kaum buruh yang terlibat di dalam ekonomi kapitalisme, menyiasati cara bagaimana mengambil keuntungan material dari industri tersebut, bagaimana melawan eksploitasi, hingga bagaimana melakukan revolusi dalam kepemilikan industri.

Tradisi pendidikan pesantren adalah tradisi hubungan antara guru dan murid. Sang guru tidak hanya melatih keterampilan sang murid, tetapi juga membentuk kepribadiannya. Praktik latihan dan proses berguru di pesantren tidak dilakukan dengan cara duduk di dalam kelas dengan jadwal yang pasti, tetapi sebuah proses bermasyarakat dalam menjalani kehidupan. Di pesantren, latihan dan proses berguru berlangsung secara perlahan dalam bentuk magang atau nyantrik, menjadi asisten dan pembantu pribadi.

Bermasyarakat dan menjalani hidup adalah inti pemahaman keagamaan kalangan pesantren yang mengamalkan ajaran Abl as-sunnah wa al-jamâ'ah, (Aswaja), yakni berjalan dengan sendirinya, tanpa ada pengarahan dari sang guru. Guru tidak memberitahu apa yang harus dikerjakan, tapi dia menegur kalau ada kesalahan. Ini yang disebut pesantren sebagai fungsi ideologi. Kaum pesantren, bagaikan musisi jazz, mereka saling berinteraksi, kemudian membentuk satu kesatuan proses, tanpa ada pengarahan dan rencana sebelumnya. Semuanya dilakukan secara bersama dalam proses, sehingga praktik keagaman dan kebudayaan mereka tidak pernah berhenti. Tradisi dan praktik kebudayaan lahir 
setiap hari. Ia selalu dipentaskan dan dipanggungkan, dihadirkan dan diinvensi. Segalanya menjadi baru dan aktual, karena secara spiritual mereka berusaha untuk melakukan adaptasi, aktualisasi, dan interpretasi. Dalam tradisi pesantren dikenal tiga unsur pokok/basis, yaitu: desa, kitab kuning, dan mesjid-pondok. Ini merupakan prinsip panutan hidup dan sekaligus merupakan jiwa kebudayaan. Dalam tradisi Bali ada desa, kala, dan patra; tempat, waktu, dan suasana. Di Jawa ada empan, papan, dan winiraos.

Kiai adalah figur utama proses nyantri. Ia pimpinan yang mengarahkan proses beragama dan berkebudayaan. Melaluinya, karakter ideal sebuah pendidikan akan tercapai, tradisi digerakkan, diamalkan, dimulai, dan diakhiri. Melaluinya santri jadi mengenal seluk-beluk kehidupan, kondisi masyarakat, serta arah dan tantangan perjalanan peradaban. Selain berargumentasi, melakukan diskusi, munaqasyah, ber-babtsul masâil, juga melakukan "meditasi dan bicara tanpa kata-kata". Mereka tidak semata-mata membuat tradisi tetap hidup, berkebudayaan dan mengamalkan agama, tapi juga bagaimana membuat hidup ini secara kosmologis, penuh keseimbangan.

Tradisi belajar di pesantren, yakni nyantri dan berguru, adalah sebuah upacara bersama. Nyantri dan berguru berarti segala sesuatu yang bisa dinikmati dengan panca indera, lahir, dan batin. Tidak ada batasan umur, asal-usul sosial, genealogi maupun bahasa. Nyantri bukan hanya proses belajar-mengajar, tapi ia sesuatu yang mengincar jiwa kaum santri. Tradisi nyantri memerlukan pengembaraan jiwa yang aktif, yang lain hanya pendukung. Di tangan sang kiai, pengembaraan itu tidak menjadi perintah yang pasti. Tapi bagaikan isyarat yang memancing santri dan masyarakat memasuki suasana mencipta dari sesuatu yang tidak pernah jelas, sebelum benar-benar terjadi. Improvisasi, seperti halnya tajdîd atau al-muhâfazhah merupakan tempat mengaplikasikan desa-kala-patra. Pesantren membuat suasana pendidikan menjadi aktual. Nyantri, dengan demikian, adalah sebuah usaha untuk hidup bersama tradisi. Tradisi atas sesuatu yang hidup, tumbuh dan berkembang sebagai bagian dari masa kini. Dalam konteks nyantri ini, sang guru hadir seperti halnya sang sutradara. Di dalam sebuah kelompok yang akan menonton sesuatu sebagai sebuah pertunjukan, sutradara adalah seorang pencipta. Dia menciptakan dirinya lewat pemain dan segala sesuatu yang nampak dalam tontonan. Tontonan yang kemudian dinikmati oleh penonton sebagai sebuah pertunjukan adalah sebuah ciptaan dari berbagai pribadi pemain, namun pada akhirnya adalah suara jiwa langsung dari sang sutradara. Seperti inilah kiai sebagai ideolog, yang menggerakkan tradisi, dan mentradisikan gerakan, di mana masing-masing menjalankan peranannya, tapi ruh dari lakonan itu adalah tetap berasal dari sang guru.

Dalam praktik berguru atau nyantri, sang kiai membuat dan melatih seseorang menjadi "pemain". Pemain yang tidak terlatih sebagai pemain tontonan seringkali amat sulit untuk berpartisipasi dalam tontonan yang memiliki jiwa berbeda dengan pertunjukan. Oleh karena itu, nyantri adalah memperlakukan masyarakat menjadi pesantren dalam skala besar. Setelah siap 
sebagai pemain, sang kiai sebagai guru memberikan perintah agar membawa sebuah misi yaitu Amrih mashlahate kawulaning Allah sedaya sarta amrih karaharjane negari lestarine agami Islam. Misi ini dilakonkan oleh orang pesantren dalam ideologi kebangsaan, untuk disampaikan kepada masyarakat, komunitas yang lebih luas lagi, kepada audiens, stakeholders, atau kepada penonton. Dalam pertunjukan/tontonan, para pemain bekerjasama seperti sepasukan prajurit dalam perang atau seperti pemain sepakbola melakukan total football untuk menciptakan tontonan.

Sang kiai sebagai guru tidak mengajarkan kaidah umum tentang pertunjukan atau seni akting. Dia mengajarkan satu bahasa khusus yang paling diperlukan untuk lakon kehidupan, yakni kemasyarakatan, kebangsaan, komunisme, anti-kolonialisme, dan lain-lain yang dipilihnya. Kaidah umum akan diajarkan bila diperlukan, tapi tidak untuk dipegang sebagai patokan, hanya sebagai pengetahuan. Pengetahuan bukan merupakan tujuan, tapi usaha untuk mengamankan misi, menyampaikan lakon kemasyarakatan, kebangsaan, dan antikolonialisme, agar sampai kepada masyarakat. Ini adalah sebuah bahasa pendidikan. Sebuah idiom, sebuah kerajaan teater dengan ideologi spiritual dan keyakinannya yang tersendiri. Pesantren tidak mungkin memproduksi pemain yang bisa dipakai oleh kelompok lain, pro kolonial, diuntungkan kolonialisme, kecuali-menurut kaki tangan penjajah dan antek-anteknya; memiliki ideologi yang sama.

Filosofi dasar lakon pesantren adalah bertolak dari "Yang Ada". Pesantren berupaya menerima apa yang ada di tangan dan di sekitar. Mereka melakukan optimasi dari yang ada untuk mencapai yang mereka citakan. Seluruh peralatan, kebutuhan, tempat bermain, cerita, pemain pendukung, kami (pesantren) manfaatkan dari yang ada. Tidak berarti dengan menerima yang ada, mereka menjadi terbatas. Justru dengan mengerti keterbatasan yang nyata, pesantren memperoleh peluang melakukan/mendapatkan yang harus ada. Itu yang mereka sebut kreativitas. Dengan modal kreativitas, hampir tidak ada yang tidak mungkin.

Mencipta menjadi pekerjaan rutin. Pesantren terus bekerja keras, memeras otak, mengoptimalkan hampir segala sesuatu dan menaklukannya dengan kreativitas. Jika tidak seperti itu, pesantren tidak akan mampu bermain teater. Berproduksi menjadi semacam proses berjuang. Dengan mencipta dan menjaga tradisi kepesantrenan, tradisi keulamaan, berarti kami mencipta sesuatu dari yang seadanya. Untuk tidak menjadi seadanya harus dilakukan akrobatik pemikiran dan interpretasi yang kadangkala bisa berarti penukaran sudut pandangan serta penjungkirbalikan nilai artistik yang mapan. Di sini, filsafat kesederhanaan (qanâab), sebagai basis ideologi pesantren menjadi semacam usaha perang gerilya, menaklukkan keterbatasan. Usaha yang tidak terbatas kepada penciptaan setting dan lakon, tapi sudah meluas menjadi usaha menciptakan formula baru dalam menilai tradisi kepesantrenan. Ini sebuah meditasi. Bagaimana pun, seluruh aspek tindakannya adalah darurat, diperlukan kiat, akal, serta sudut (angle 
kamera) memandang yang baru. Karena itu, hasilnya juga berbeda dengan hasil produksi yang bertradisi, beragama, dan berkebudayaan lain. Tentu hal ini dapat terjadi ketika dalam keadaan normal. Ketika tidak normal tak jarang ada distorsi, ada kelainan, penyimpangan (anomali) bahkan pemutarbalikan yang kemudian secara fantastis bisa berubah menjadi orisinalitas/keunikan. Kesederhanaan adalah hidup selaras dengan alam dan sekaligus berkarya. Itu adalah keindahan yang memancarkan kebenaran.

Kaum pesantren mengajak orang memikirkan sekali lagi segala sesuatu yang sudah pernah disimpulkan atau yang sudah diterima sebagai simpulan. Bukan untuk mengajak orang berbalik langkah atau mengingkari diri, tetapi untuk mengaktualisasikan segala keyakinannya setiap saat. Ke-syuyukhiyah-an sang kiai lebih merupakan pengaturan strategi. Dalam mengatur strategi bukan hanya diperlukan akal tapi juga insting. Ada strategi bahasa, ruang, visual, psikologi, juga manajemen, bahkan menyerang yang dijalankan pesantren. Ini menjelaskan mengapa pesantren kemudian mengajarkan santri bela diri dan ilmu kanuragan.

Dalam tradisi pesantren, seorang kiai adalah seorang jenderal perang yang memiliki kekuasaan sangat besar dan tak terbantahkan dalam proses berproduksi. Kiai adalah pemimpin spiritual, mahir segala taktik berperang dan sutradara panggung/lanskap kebudayaan, keagamaan, dan kenegaraan. Tidak semua orang mampu dan bisa menjadi kiai sekaligus jenderal. Saat ini, banyak yang mengaku kiai namun hanya mampu menjadi pelaksana titah sang jenderal.

Kiai adalah pemimpin yang mampu menciptakan tontonan sekaligus tuntunan (uswab) dalam diri masyarakatnya. Dalam diri penonton, ia memberikan pengalaman spiritual kepada penonton, bukan hanya mencipta adegan bagus di panggung tetapi melakoni peristiwa spiritual untuk mencari jatidiri manusia. Ia bukan sekedar hubungan kerja, pengetahuan, tapi juga pengabdian. Ia merupakan kesempatan untuk nyantrik (menemukan diri). Sebuah pendidikan jiwa, bagi para santri bukan hanya mengajarkan seni berperilaku dan berpengetahuan, tapi juga bersikap terhadap berbagai aspek kehidupan. Pesantren adalah sebuah padepokan untuk melakukan pemantapan sikap dan kepribadian, sehingga akhirnya mampu menyampaikan suara, sikap atau pendiriannya untuk berbagai fenomena sosial-politik bahkan juga spiritual. Zuhri, dengan melihat cara penampilan sang santri di panggung dan di luar panggung, menyebutkan bahwa pesantren adalah teater atau seni pertunjukan seperti halnya wayang atau komedie stamboel yang ditampilkan di desa-desa sebagai sebuah komunitas spiritual. Ini bisa dibandingkan dengan teater modern sebagaimana yang dipanggungkan dan dipraktikkan oleh Putu Wijaya yang menyebut teater sebagai padepokan, sebagai kesempatan untuk mempelajari banyak hal dari seorang sutradara yang bertindak sebagai guru spiritual. Teater bukan sekedar hubungan kerja, tetapi pengabdian. Teater adalah sebuah kesempatan untuk nyantrik, menemukan diri, mendidik jiwa anggotanya. Teater bukan hanya mengajarkan seni akting dan olah vokal, tetapi juga menggubah dan melakoni, dengan laku dan sikap atas seluruh aspek kehidupan. Teater bukan 
sekadar pertunjukan hiburan tetapi juga sebuah komunitas spiritual (Wijaya, 1999: 297).

Di pesantren, aspek berperilaku, berpengetahuan, bersikap, bersuara, dan berpendirian itu ditanamkan, dipupuk, dan disebar. Berpengetahuan adalah menjadi ‘alim, yakni mampu memproduksi pengetahuan dan kebudayaan. Berperilaku adalah berakhlak, berketerampilan, dan berpendidikan karakter. Bersikap, bersuara dan berpendirian adalah mampu menyatakan, menyebarluaskan, mewariskan nilai, serta membelajarkan nilai kebangsaan, ideologi tanah-air, sekaligus aktif dalam gerakan kebangsaan. Ini adalah cara berbahasa pesantren dalam menyatakan dan menyempurnakan ada-diri kita menjadi manusiawi dan semakin manusiawi. Hanya melalui manusia-manusia seperti ini, kebebasan bisa diraih. Kebebasan/kemerdekaan adalah perkara yang bersifat batin-dalam dan rûbiyyah. Tanda pengenal kemuliaan bahasa kebebasan/kemerdekaan adalah kejujuran dan kewajaran.

Kiai menuntun, memberi arah, menjiwai gerak-gerik fisik manusiawi para santrinya, sehingga sikap dan gerak-gerik mereka memiliki hakikat dan arti, yang mampu mengatasi/melampaui (beyond) dunia flora, fauna dan alam yang materi belaka. Pesantren bukan memupuk manusia menjadi sosok yang cinta kepada dunia materi dan lupa dunia batin. Pada dunia batin, pesantren mencahayakan pengangkatan manusia pada nilai yang lebih luhur. Selain unsur guna/manfaat fisik-materi, para santri ditempa untuk menemukan, berkarya, bekerja dan berbuat sesuatu demi citra kebudayaanya. Hadlratussyekh ketika nyantri kepada Kiai Cholil Bangkalan, hanya disuruh angkat air, namun ia memikirkan, mengolahnya menjadi pertanyaan, kemudian ia mengerjakan dan menyelesaikan tugas tersebut dengan keindahan bentuk (Aristoteles-form: prinsip-hidup-yang bersifat permanen) dan citra yang memancar secara cemerlang.

Walaupun hanya pondok, yang secara fisik sangat sederhana, terlihat kumuh dan bahkan (jorok), tetapi ia menggambarkan dan membahasakan jiwa elegan orang pesantren, yang rajin dan cerdas dalam menggunakan modal anugerah bumi-alam-tanah-air. Kesederhanaan bukan dilihat secara fisik semata yang tampaknya kumuh atau jorok, tapi juga dimaknai sebagai pencitraan dalam bentuk totalitasnya. Mengatur diri sendiri, dengan mengingat tertib persatuan dalam kehidupan. Secara tertib dan damai, pesantren mengajarkan santri untuk tumbuh menurut kodrat. Pendidikan adalah usaha kebudayaan, yang mengarah pada jiwa raga anak, menuju kepada adab kemanusiaan. Kodrat hidup manusia menunjukkan adanya segala kekuatan sebagai bekal hidup, untuk pemeliharaan dan kemajuan hidupnya, agar tercapai keselamatan lahir dan kebahagiaan hidup, baik untuk diri maupun untuk masyarakat. Pelajaran pertama dalam pesantren adalah bagaimana kita memulai dari diri sendiri (ibda bi nafsika) untuk mencapai keselamatan di dunia dan di akhirat. Ia kemudian tidak berhenti di sini. Ia harus melanjutkannya ke tahap yang lebih memberi kemaslahatan bagi orang lain. Orang pesantren sering mengutip hadis, "Khair an-nâs anfa'uhum li an-nâs", agar mau berkorban untuk menambah kekuatan batin. Karena ada cita-cita, pendirian 
dan teladan kaum santri yakni gurunya (kiai), yang dalam imajinasi dan sejarah pengalaman mereka ada pada contoh para ulama pembela tanah dan bangsa mereka, maka yang menakutkan para penguasa adalah makin banyak contoh dan teladan makin kuat dampak dan pengaruh pembelajaran komunitas pesantren. Demikian pula arti kemerdekaan yang lahir dari semangat independen dan berdikari itu, adalah hak dan kewajiban mengurus diri-sendiri dengan memperhatikan tertib damainya masyarakat (Madjelis Luhur Taman Siswa, 1952: 45-64). Semakin kuat dan kaya bahasa mereka dalam iklim kemerdekaan, makin kuat pula daya dorong dan daya dobrak untuk merdeka. Jika kita bandingkan dengan makna pendidikan dalam kebudayaan Cina daratan, tampak bahwa pendidikan adalah 'darah daging bangsa ini' (Hughes, 1937: 155).

Dalam pesan pendidikan yang ditawarkan oleh sesepuh pendidikan di daratan Cina, Liang Chi-chao, di penghujung abad ke-19 disebutkan, "Orang yang berkepentingan dengan pengembangan dunia pendidikan harus memperhatikan dua prinsip pokok pendidikan, yaitu: pertama, pendidikan sebagai sarana untuk membentuk kemampuan bekerja penduduk negeri ini; kedua, sebagai sarana utama untuk memahami pengalaman di dunia ini, menguji berbagai kecenderungan dunia, dan untuk memahami karakter khusus bangsa dengan sebuah pandangan demi membangkitkan segenap kekuatan". Pendidikan itu untuk membentuk karakter, mengasah siswa agar menjadi sebuah kekuatan yang independen dan untuk bertahan di dunia ini (Hughes, 1937: 164-165). Dari catatan Hughes ini, model pendidikan kebangsaan Bangsa Cina ini kemudian dihacurkan oleh bangsa Barat yang masuk ke sana, dengan mendirikan sekolah misionaris, yang menjadikan anak didik terasing dan tercerabut dari akar masyarakat Cina.

Segala hidup jiwa selalu berelasi dengan bangsanya. Baik pikiran, perasaan, maupun kemauannya, semua terikat dengan kebangsaannya. Semua orang menjadi besar dan mendapat kemajuan dengan perantaraan bangsanya. Jiwa anak mendapat pengaruh dan mendapat cap dari bangsanya. Jiwa sang anak tidak akan bisa dikenal kalau anak tidak dipandang sebagai anak bangsa.

\section{Aqwâlu Haqqin Urîda biha al-Bâthil lil Pesantren}

Selama sepuluh tahun terakhir ini telah terjadi upaya "modernisasi madrasah", "pembaruan pesantren" dan "reformasi Islam tradisional". Mulai Hugronje hingga Geertz, dari Noer hingga Azra, dari para peneliti asing hingga peneliti Litbang Kementerian Agama dan kementrian lain yang meneliti pesantren, semuanya digerakan oleh desain memotong garis kesejarahan orang pesantren dengan tradisi kebangsaannnya, serta mengacaukan hakikat dan keberadaan tradisi Aswaja di Nusantara. Agenda mereka hanya mengangkat alternatifnya, yakni Wababi. Mentor yang dijadikan referensi buat pesantren adalah selalu para sarjana lulusan Barat dengan titel Ph.D. hingga profesor.

Dalam agenda perubahan di atas, tidak lagi muncul strategi pesantren dan suara para ulama Aswaja dalam menyiasati sekolah modern. Seperti pengalaman 
orang Madura yang santri namun tetap bertekad menyekolahkan anaknya di sekolah Belanda dan mereka menyempatkan juga untuk dididik di pesantren. Mereka beranggapan bahwa sekolah modern akan tambah memperkuat dasar pendidikan mereka di pesantren, selain untuk mendalami pengetahuan keagamaan juga membangun relasi dan komunikasi yang akrab dengan rakyat. Zuhri mendirikan madrasah modern berbahasa asing, tapi tetap mengacu kepada induknya, sistem pesantren di bawah komando para kiai. Pada permulaan tahun 1938 Zuhri pulang dari Solo dengan memperoleh ijazah. Ia berkata, "Aku benarbenar telah menjadi guru. Aku mengajar di Madrasah Nabdlatul Ulama, di Islamitisch Westerse School (Sekolah Islam berbahasa Barat, yakni bahasa Belanda), dan di Kulliyat al-Muallimîn wal Muballighîn. Dua macam sekolah yang belakangan ini juga bernaung di bawah asuhan Nabdlatul Ulama. Di madrasah aku dipanggil ustadz, tetapi di sekolah yang berbau Belanda ini, aku dipanggil meneer oleh anak murid" (Zuhri, 2001/1974: 133-135).

Tentang Islamitisch Westerse School (IWS-NU) ini, Zuhri menulis, "Semenjak di Sokaraja didirikan sekolah Islam yang dilengkapi bahasa Belanda bernama Islamitisch Westerse School (Sekolah Islam dengan bahasa Barat), aku mendapat tugas menjadi guru agama. Sekolah tersebut diasuh oleh Meneer Sunarko dan Juffrouw Sutiah sebagai guru pembantu". Di usia 19 tahun, Zuhri bersama Raden Sunarko dan dukungan kiai, mendirikan sekolah ini pada tahun 1938. Setiap bulan ia memperoleh gaji 5 gulden. Tapi kemudian sekolah tersebut dipaksa ditutup oleh pemerintahan pendudukan Jepang di Jawa pada 1942. "Sekolah yang memberikan pelajaran bahasa Belanda dilarang," kenang Zuhri, "Dengan sendirinya sekolah dimana aku mengajar agama, Islamitisch Westerse School NU, ditutup. Para muridnya disalurkan ke madrasah atau sekolah rakyat. Guru-guru IWS-NU harus bisa mencari lapangan kerja lain" (Zuhri, 2001/1974: 133-135 dan 1987: 175-195).

Agenda-agenda "modernisasi madrasah", "pembaruan pesantren" dan "reformasi sistem pendidikan Islam tradisional" ini, hanya mereduksi pesantren sebagai sekolah yang tidak ada bedanya dengan sekolah lain di negeri ini. Sistem yang diberlakukan kepada pesantren adalah sistem sekolahan formalis. Sehingga wajar dalam logika anak sekolahan, madrasah dipertentangkan dengan pesantren, pesantren dibandingkan dengan sekolah unggulan internasional, atau dengan Harvard, Oxford, Cambridge, dan Mc Gill. Ini yang perlu diluruskan terlebih dahulu. Pesantren sebagai pendidikan karakter kebangsaan adalah pendidikan seumur hidup, yang mendidik dan memperlakukan anak bangsa ini untuk hidup sepanjang hayat bangsa ini, dengan segenap sumber daya alam dan manusianya. Pendidikan pesantren bukan untuk mendesain diri bergantung kepada bangsa lain dan mengandalkan resources bangsa luar. Pesantren memerlakukan anak didik dalam segenap totalitasnya, mulai dari segi fisik, batin, individu, sosial, dalam hidup privat, pembentukan pribadi yang utuh, dalam hidup dan pergaulan bermasyarakat dan berbangsa, hingga persiapan untuk hidup di akhirat kelak, yang semua itu disesuaikan dengan segenap kebutuhan bangsa. 
Dalam agenda "modernisasi madrasah", "pembaruan pesantren" dan "reformasi sistem pendidikan Islam tradisional", kekuatan dan modal pesantren sebagai perekat kebangsaan juga direduksi dengan memandangnya "hanya" sebagai "pendidikan Islam". Dari titik ini ditarik satu cap tersendiri bahwa pesantren itu sektarian, eksklusif, hingga yang paling ekstrem, sarang teroris, kelompok garis keras atau radikalisme Islam. Label ini jelas merugikan pesantren yang selama ratusan tahun menjadi oase kebudayaan rakyat atas berbagai macam komunitas. Sebenarnya, pesantren adalah pendidikan lintas-komunitas. Seperti Kiai Sadrach yang belajar di Pesantren Tegalsari, Ponorogo; demikian pula dengan komunitas abangan dan Kejawen, kalangan santri, bangsawan, dan rajaraja di Nusantara, para pujangga kraton juga berguru ke pesantren, hingga para jago dan jawara menimba ilmu kanuragan dari para kiai pesantren. Label sektarian kepada pesantren akan membuat komunitas penyangganya akan lari dan meninggalkan pesantren. Ini misalnya, ditunjukan oleh seorang tokoh desa penganut Kejawen tentang pendiri pesantren pertama di daerahnya, "Kami sangat berterima kasih kepada Kiai Chudlori (pendiri pesantren pertama di Tegalrejo, Magelang, yang juga kiainya Gus Dur) dan putranya, atas jasa mereka sebagai pelopor dalam memuliakan makam guru kami. Saya seorang kejawen, akan tetapi saya juga seorang Muslim. Saya mempunyai tujuan yang sama dengan tujuan orang di pesantren, kita menyembah Tuhan yang sama, kita menjunjung nabi yang sama, dan kita juga memuliakan wali yang sama. Perbedaan di antara kita hanya, saya tidak bisa membaca kitab Arab, sedangkan para kiai bisa" (Pranowo, 2009: 224).

Di masa pergerakan dan perlawanan terhadap penjajah dan antekanteknya, pesantren merupakan oase perlindungan bagi para kaum nasionalis dan pemberontak terhadap penjajah. Ada puluhan contoh kalangan nasionalis berlindung di pesantren dan jejer pandita (tudangguru dalam istilah orang Bugis) dengan para kiai dan ulama pesantren. Jejer pandita berarti audiensi dengan ulama, guru, atau kiai. Konsep ini berasal dari satu adegan dalam cerita pewayangan yang menggambarkan pertemuan seorang tokoh protagonis (satria) dengan seorang guru spiritual (pandita) yang menjadi pembimbingnya dalam menegakkan kebenaran dan melawan kezhaliman. Dalam tradisi Jawa, jejer pandita berarti menghadap kepada sang agamawan di tempat kediamannya, yakni di hutan, lereng gunung, atau tempat terpencil. Di daerah itu biasa ditemukan sang pertapa, resi atau agamawan, yang mendalami rahasia tumbuhan dan benda, merawat pahlawan yang terluka serta mewariskan ilmu kepadanya. Oleh kalangan pesantren, tradisi jejer pandita ini di-Aswaja-kan dengan mengaitkannya dengan ajaran nasehat-menasehati (wa tawâshau bi al-haq wa tawâshau bi ash-shabr). Dalam konteks ini, posisi pandita (kiai, ulama) sebagai ideolog dikukuhkan, sementara sang satria adalah sang pelaksana-eksekutor di lapangan. Tradisi jejer pandita ini selanjutnya menjustifikasi keberadaan dua struktur kepemimpinan dalam NU, syûriyah dan tanfídriyah. Seperti disimbolkan dalam relasi antara Hadlratussyekh Hasyim Asy'ari dan Kiai Khasbullah, dan antara Kiai Khasbullah dengan Haji 
Hasan Gipo. Di satu pihak menjadi ideolog lembaga, yakni syûriah, yang terdiri dari unsur kiai, ulama atau tokoh santri, di pihak lain, tanfídziyah, yakni pelaksana para ideolog, yang kebanyakan berlatar belakang satria atau yang berpotensi menempati posisi satria (cendekiawan, bangsawan, pengusaha, dan kaum santri). Pahlawannya adalah pelaksana ini. Sang guru tidak dikenal, tapi posisinya jelas sebagai dalang/aktor di balik panggung atau king-maker. Ini yang kita lihat dalam relasi antara kaum pesantren dan raja Jawa. Mereka banyak menjadi penasehat, bahkan sebagai ideolog yang menentukan politik istana. Demikian pula dalam sejarah para pahlawan nasional, Untung Surapati jejer pandita dengan Kiai Ebun (Tuan Syekh). Sultan Nuku dari Tidore, Maluku, jejer pandita kepada KH. Oemar. Pangeran Diponegoro jejer pandita dengan Kiai Taftazani dari Pesantren Mlangi Yogyakarta. Soekarno jejer pandita dengan gurunya di Pesantren Sukanegara, Cianjur. Tan Malaka jejer pandita dengan Hadlratussyekh di Jombang pada tahun 1945 sebelum keluarnya Resolusi Jihad. Jenderal Sudirman ketika bergerilya, jejer pandita kepada Kiai Mahfudz Ponorogo, yang memberinya tongkat dan keris. Berkat pemberian sang kiai, Panglima Besar TNI ini selamat dari upaya pembunuhan tentara Belanda yang mengepungnya di daerah gerilya (Lombard, 1983) (Soeharto, 1982: 14 dan Tjokroaminoto, 2000: 131-132).

Sukarni, aktor pemuda dalam penculikan Soekarno dan Hatta menjelang Proklamasi 17 Agustus 1945 di Jawa Barat juga pernah jejer pandita di pesantren Jawa Timur. Sukarni bersembunyi di salah satu Pondok Pesantren di Kediri, Plosomine, pimpinan Haji Ilyas. Di sana dia menetap selama kurang lebih tiga bulan sambil memberikan pelajaran politik dan bahasa Belanda kepada para pemuda-pemudi penghuni pondok. Sang kiai juga orang pergerakan. Setelah Belanda kemudian mencium kehadiran Sukarni di Plosomine, Kediri, maka PID (polisi intel Belanda) dikerahkan. Sukarni yang tahu gelagat kembali melarikan diri. Ia lari ke Banyuwangi. Berlagak sebagai pedagang kelontong, dengan menggunakan sepeda ia berhasil menyelinap ke pondok pesantren di Banyuwangi (Koto, dalam Mustoffa (penyunting), 1986: 24). Kiai Siradj dan Kiai Kholid, orang pesantren dari Blitar, melindungi Supriyadi dan para anak buahnya ketika pada Februari 1945 mereka melakukan pemberontakan Peta terhadap pendudukan Jepang untuk Indonesia merdeka. Ketika pemberontakan itu ditumpas Jepang, kedua kiai ini sempat ditangkap militer Jepang dan disiksa dengan kejam. Kiai Siradj kemudian wafat dalam penjara - Allah yarhambu(Anhar, 2007: 53). Tan Malaka berlindung di Pesantren Tebuireng Jombang (Poeze, 2008).

Di masa revolusi kemerdekaan tahun 1940-an, kerjasama ulama-jawara makin diperkuat, bahkan menjadi aktor revolusi sosial di sejumlah daerah. Salah seorang tokoh revolusi sosial di Tegal, Jawa Tengah, November 1945, Sakhyani, dikenal dengan nama panggilan Kutil, asal Madura, berhasil menjatuhkan seorang bupati, dan menggantikannya dengan gurunya bernama Kiai Abu Syuja'i, yang pernah nyantri di Pesantren Tebuireng dan menjadi santri Hadhratussyekh Hasyim Asy’ari. Kiai Syuja'i dipilih untuk menjadi pemimpin mereka dan 
didukung oleh pemuda, pesantren, Muslim-nasionalis dan jawara. Kiai antikolonial dan aktif di PSII ini dijemput dari kampungnya, dan dibawa ke kota. Di bulan November 1945 itu, rakyat sudah berkumpul untuk melihat sendiri bupati barunya sebagai hasil revolusi yang mereka buat. Ketika Kiai Abu Syuja'i tampil ke mimbar untuk berpidato, susana jadi hening. Orang terpukau menyaksikan seorang yang tampan, tinggi, agak sedikit kurus, mengenakan celana panjang, kemeja putih dan peci hitam. Ia berbicara dengan tenang, jelas, dan lancar. Kadang-kadang menyelipkan kata-kata Belanda dengan ucapan yang tepat, dan kutipan ayat al-Qur'an. Saat itu kalangan Muslim nasionalis di kota itu tampak puas. Para pemimpin Komite Nasional Indonesia-Tegal terperanjat melihat bahwa seorang kiai dari desa tampil sangat mengesankan sebagai bupati (Lucas, 1989).

Keislaman pesantren bukan keislaman model Wababi atau konstruk orientalis Islamic studies yang dengan mudah menarik garis sekat antara yang puritan, murni, dan yang dianggap masih "sinkretik" (dinilai masih ada kotoran budaya). Keislaman pesantren bukan keislaman ala racikan modernis-orientalis yang dibaukan di perguruan tinggi di Amerika, Eropa atau Australia, yang kemudian dijiplak di Indonesia untuk program de-nasionalisasi dalam rangka melihat Islam sebagai sebuah normatif-abstraksi yang kehilangan akar dan basisnya atas bangsa. Keislaman pesantren bukan seperti hasil racikan para orientalis dan muridnya yang memandang Islam sebagai doktrin dan peradaban yang lepas sama sekali dari akar teks kesejarahan Islam Nusantara, dan dianggap sebagai anti-tesis dari nasionalisme/kebangssaan. Racikan Geertz, Federspiel, dan Feith memandang bahwa kelompok Islam reformis di Indonesia itu anti Pancasila dan anti nasionalisme (Federspiel, 2004 dan 1977: 39-85). Meski nasionalisme ada juga dalam studi mereka, tapi mereka kemudian mencari sesuatu yang "islami”, yang bahkan diracik oleh satu kemungkinan tentang adanya "nasionalisme yang Islam". Dulu disebut "nasionalisme religius" dan kini disebut "Islamic nationhood".

Dalam konstruk "Islamic nationhood", orang pesantren dan NU tidak punya tempat, bila dibandingkan misalnya dengan Sarekat Islam/jurnal alMunir/Seruan Islam dari Al-Azhar yang dianggap modernis-reformis, pengikut Afghani dan Abduh. Tasjwiroel Afkear, embrio NU, yang didirikan oleh Kiai Khasbullah, disebut "unIslamic" (Laffan, 2003: 259).

Dari front yang berbeda, pesantren dicap sinkretik, dianggap mencampur adukan berbagai kebatilan, bid'ah dan syirik ke dalam agama Islam. Ini dilihat ketika pesantren merawat tradisi nusantara, yang menjadi penjaga dari tradisi kejawaan. Mereka menyebut ideologi pesantren yang berkiblat ke Walisongo dianggap sebagai cerminan cara beragama sinkretik, yang oleh mereka dianggap menunjukkan "belum sempurna dan tuntasnya proses Islamisasi secara menyeluruh (kaffah) di Tanah Jawa. Maraknya praktik slametan dan kendurenan yang digelar oleh kalangan pesantren dianggap sebagai cara menjadi Muslim yang belum sempurna. Ini membuat komunitas santri menjauh dari tradisi nusantara, 
dan berlomba-lomba "membersihkan diri" dari segenap yang dianggap "tidak Islami”" kemudian beramai-ramai cuci baju menjadi seputih-putihnya, sepuritanpuritannya atau semurni-murninya. Orang pesantren dibuat jauh dari komunitas bangsa penyangganya, terkucil, kesepian, dan akhirnya tidak laku, bangkrut atau bubar di negeri sendiri.

\section{Dari Ideologi Pesantren ke Ideologi Keindonesiaan}

Pesantren bukan semata-mata pendidikan Islam. Pesantren adalah pendidikan karakter yang hidup dalam konteks berbangsa, bergumul dengan hakikat dan jatidiri bangsa, dan berproses ke dalam satu cara beragama di mana yang dipromosikan adalah "Amrib mashlahate kawulaning Allah sedaya sarta amríh karaharjane negari lestarine agami Islam" (Berjuang untuk kepentingan kemaslahatan para hamba Allah semua, untuk kesejahteraan negeri, serta untuk kepentingan kelestarian agama Islam). Pandangan ini disampaikan Kiai Maja selaku ideolog Perang Diponegoro. Maja berperan besar dalam menggerakkan jaringan komunitas pesantren dan desa perdikan untuk berjuang bahu-membahu bersama Diponegoro. Selama hidupnya Maja dikenal sebagai seorang ulama yang mobilitasnya tinggi. Mengikuti tradisi santri kelana, Maja punya banyak relasi dan jaringan dengan pusat keagamaan dan politik di Jawa hingga ke Bali. Beliau pernah menjadi penghubung antara Kraton Surakarta dan Kerajaan Buleleng di Bali. Jaringan orang pesantren dengan Bali, meski berbeda agama dan kepercayaan, sudah terbangun sejak abad ke-18. Ada ikatan politik dan kebudayaan di antara mereka, misalnya perlindungan bagi kalangan santri yang lari ke Bali untuk menghindari penangkapan Kompeni hingga pemberian kebebasan beragama bagi komunitas Muslim di pesisir utara Bali. Karena terlalu gerahnya pemerintah kolonial Inggris, Maja ditangkap pada bulan Juli 1812. Pembatasan kemudian diberlakukan kepada orang pesantren yang sebelumnya bisa leluasa keluar-masuk kraton. Mobilitas Maja dan jejaringnya menjadi obyek penjinakan Belanda untuk mematahkan perlawanan orang Jawa (Sagimun, 1965, Babcock, 1981, Carey, 1986, Alfian, 1992; dan Ibrahim 1992). Jadi, keislaman adalah salah satu komponen dari ideologi orang pesantren, selain komponen kedaulatan, kemerdekaan, kesejahteraan, dan kemaslahatan umat manusia.

Dalam ungkapan Maja, ada tiga komponen yang tertanam dalam ideologi nasionalis orang pesantren: pertama, "mashlabate", yakni kemaslahatan hamba Allah semua, tanpa memandang perbedaan agama atau keyakinan (hal ini menjadi dasar kebangsaan yang bhineka); kedua, "karaharjane", yaitu kepentingan kesejahteraan negara dan tanah air; ketiga, "lestarine agami Islam", kepentingan keagamaan, yakni aspek karakter dan ideologisasi paham keagamaan abl as-sunnah wal jamâ'ah (Aswaja).

Posisi pesantren sebagai penjaga tradisi Aswaja memungkinkan orang pesantren menjadi pilar utama penyangga tubuh dan berkembanganya bangsa ini. Dalam sejarah nusantara, sejak masa Wali Songo, tradisi Aswaja sudah menjadi senjata untuk menaklukkan penjajah asing. Dalam bahasa lain adalah 
"kemenangan Jawa berkat agama Islam Jawa (Aswaja)". Hal ini dapat dilihat dari cara orang pesantren meracik ide tentang Ratu Adil sejak abad ke-18 di Jawa, yang merupakan salah satu imajinasi politik-kolektif (al-mikhyal al-jamâ'i) kalangan pesantren sejak abad ke-18, yakni tentang cita-cita ada tatanan adil dan kesejahteraan bagi negeri pasca penjajahan.

Ratu adil bisa berarti sebuah persona atau individu yang akan berkuasa dan membawa kemaslahatan kepada penduduk negeri atau sebuah idealisme tentang perombakan struktural menjadi struktur baru yang sesuai dengan kemaslahatan umat dan bangsa. Ratu sebagai person dan sebagai sebuah struktur kekuasaan untuk keadilan, tercakup dalam pengertian Jawa klasik tentang "ratu". Raja yang duduk di singgasana dan ratu sebagai wahyu kekuasaan untuk "memayu bayuning bawana", terus mengusahakan keselamatan dan kemaslahatan dunia. Wahyu kekuasaan mencakup ideologi, struktur kelembagaan kekuasaan, hingga pelaksanaan pemerintahan. Kedua pengertian tentang ratu ini dikembangkan oleh kalangan pesantren dengan menulis-ulang dan sekaligus menafsir ulang teks Jangka Jayabaya, Serat Akbirin Jaman, Serat Jayabaya atau Pralambang Jayabaya tentang datangnya sang juru selamat (Ratu Adil). Sebagai sebuah persona, Ratu Adil itu datang dari Mekah. Sebagai sebuah wahyu kekuasaan untuk keadilan dan keselamatan, orang pesantren menyebut "ratuning Jawa" (kedaulatan dan persatuan Jawa), dan di masa pergerakan, berarti "ratuning Indonesia" (kedaulatan dan persatuan Indonesia). Dengan demikian, berbagai penafsiran selama kurun waktu 3 abad lebih dalam proses tulis dan tafsir-ulang atas teks Raja Kediri abad ke-9 ini, berkisar pada tema khas pesantren. Genealogi tersebut dapat dirunut dari sang ratu yang berasal dari Mekah, pembalikan tatanan kolonial dengan tatanan baru berdasar keadilan, persatuan Nusantara, kedaulatan bangsa dengan mengusir penjajah Belanda lewat perang sabil, dan imajinasi negara pascapenjajahan berdasar kemaslahatan berbangsa-bernegara.

Seperti ditulis Raffles dalam History of Java di awal abad ke-19, meski diduga berasal dari tradisi Jawa pra-Islam, namun semua mengakui bahwa teks ini telah mengalami modifikasi dan penulisan-kembali sesuai dengan tradisi Muslim Aswaja. Kisahnya seputar pertemuan Aji Jayabaya dengan seorang ulama dari Rum (Kesultanan Usmaniyah), dalam versi Mekah bernama Maulana Ali Syamsudin, menguraikan sebuah ramalan seperti tercantum dalam Kitab Musarrar (Musaran). Pertemuan ini dilanjutkan dengan sejumlah subcerita lain yang berintikan pertemuan ide Ratu Adil dengan konsep Aswaja tentang Imam Mahdi dalam eskatologi Islam.

Prototip cerita ini berasal dari naskah tertua dari awal abad ke-18 (sebelum tahun 1715), yang juga penuh dengan beragam penambahan dengan kata-kata kafir, sulthân, dan waliyullah. Dalam versi lain, imajinasi tentang Ratu Adil sebagai "ratu waliyullab" ditemukan dalam Serat Kanjeng Kiai Surya Raja, dikarang pada tahun 1774 oleh Sultan Hamengku Buwana II. Dahm dalam bukunya tentang Soekarno, mencatat adanya peralihan kisah "Ratu Adil" dalam ramalan Jayabaya ini dari versi kraton ke luar kraton sejak pertengahan abad ke-19. Dalam 
beragam versi luar kraton, ramalan tentang kedatangan Ratu Adil tumbuh subur, terutama di lingkungan pesantren, di mana berbagai imajinasi tentang kedatangan Ratu Adil mengalir dari sumber mata air Islam Aswaja, dari Mekah. Kiai Maulani dari Lengkong, Cirebon, Mas Malangyuda dari Rajawana Kidul, Klaten, dan Kiai Nurhakim dari Pasirwetan, adalah ulama pesantren abad ke-19 yang melakukan proses modifikasi itu. Dari tangan mereka, surat wasiat tentang hari akhir zaman banyak beredar sejak pertengahan abad ke-19 hingga awal abad ke-20. Ajaran versi Mekah membuat pengertian baru tentang Ratu Adil. Dengan surat wasiat ini, tema pembalikan tatanan ekonomi-politik kolonial saat itu (jaman balik buwono) menjadi idealisme orang pesantren. Kiai Nurhakim pada tahun 1870 mengartikan pembalikan tatanan itu sebagai penyelenggaraan reformasi agraria dan penghapusan pajak bagi para petani.

Tema berikutnya dalam "Ratu Adil" adalah kesatuan tradisi Islam-Jawa untuk mengusir Belanda. Setelah Perjanjian Gyanti pada 1755, orang pesantren berusaha semaksimal mungkin mengembalikan persatuan Jawa yang dipecahpecah oleh Belanda. Itu dimulai dari peristiwa Pakepung tahun 1790 di mana pasukan Kompeni mengepung kraton Surakarta untuk menindak Kiai Bahman, penasehat Susuhunan, yang dianggap makar terhadap Belanda karena mendakwahkan persatuan Jawa dan penyerangan terhadap loji VOC di Semarang. Dalam Serat "Kanjeng Kyai Surya Raja" diramalkan pula solusi final bagi orang Jawa: persatuan dan kemenangan atas Belanda berkat keunggulan kebudayaan Islam-Jawa, dan tercapainya kesejahteraan. Cita-cita ini kemudian dilanjutkan oleh orang pesantren ketika mereka menjadi "orang pergerakan": persatuan Indonesia, kemerdekaan dan kedaulatan bangsa dan tercapainya kesejahteraan di bawah negara-bangsa yang baru. Cita-cita ini yang menggerakkan orang NU menerima NKRI (Negara Kesatuan Republik Indonesia) sebagai bentuk final negara Indonesia. Sementara tema "perang sabil" (jihad fi sabilillah) sebagai instrumen "Ratu Adil" untuk mengusir penjajah, mulai digodok sejak pertengahan abad ke-18, ketika surat-surat Syekh Abdusshamad al-Palimbani (wafat 1788) muncul ke Tanah Jawa dibawa oleh santrinya dari Mekah. Surat tersebut memberi corak baru ide Ratu Adil karena memperjelas pengusiran penjajah Belanda dengan jihad. Beliau menulis sebuah risalah berjudul "Nashîhat al-Muslimîn wa Tadzkirat al-Mu'minîn fi Fadlâilil Jihbâd fi Sabîlillâh wa Karâmat al-Mujâhidîn fî Sabîlillâh”. Ide ini menginspirasi Kiai Taptajani, guru Pangeran Diponegoro di Tegalrejo pada tahun 1825, dalam mengkader santrinya untuk menggelar Perang Jawa dengan misi Ratu Adil.

Masalah "dikader orang lain" pernah menjadi perhatian Kiai Wahab Khasbullah dan Kiai Wahid Hasyim ketika membentuk Partai NU di tahun 1952, sebagai persiapan menuju Pemilu 1955. Salah satunya ketika mereka atau salah satunya, apakah Kiai Wahab atau Kiai Wahid, pernah mendatangi Sutan Sjahrir, tokoh PSI, partai kader modernis, untuk menanamkan kader PSI (Partai Sosialis Indonesia) di NU untuk kepentingan mengkader anak muda NU dan pesantren. Penolakan Sjahrir dan kelompok PSI saat itu untuk mengkader anak 
muda NU perlu ditanyakan lebih lanjut. Jika dibandingkan masa kini, di mana mereka bisa leluasa mengkader anak muda NU di kantong-kantong PSI di Jakarta, seperti di Utan Kayu, di DKJ (Dewan kesenian Jakarta), di Salihara Pasar Minggu, hingga di Majalah/Koran Tempo, kita pun patut bertanya, apa sebabnya orang PSI sekaliber seperti Sjahrir menolak? Bagaimana pun keberadaan Kiai Wahab dan Kiai Wahid yang dikenal berani dan licin itu, dirasakan masih terlalu kuat, sehingga menjadi sebuah hambatan atau batu sandungan kalau PSI menanamkan kadernya di NU. Kekhawatiran mereka, kader PSI mereka akan dikader oleh kiai NU untuk menjadi bagian dari kader NU yang nantinya akan membesarkan NU.

Saat ini, ketika mereka dengan mudah mengkader anak muda NU, tidak muncul lagi anak muda NU yang bisa membesarkan NU dan orang pesantren, yang membuat bangga orang NU sebagai orang NU, yang membuat bangga orang pesantren sebagai pelanjut tradisi Abl as-sunnah wal jamâ'ah. Karena mungkin di sana dilihat sudah tidak ada yang bisa menjadi batu sandungan atau hambatan untuk mengkader anak muda NU itu, dan tidak ada lagi anak muda NU yang bisa sebaliknya, melakukan writing back, yakni, mengader anak PSI untuk masuk menjadi kader NU dan pesantren. Zuhri menulis demikian tentang kiprah dan sosok seorang santri yang mempunyai jaringan luas di kalangan nasionalis. Menurut Zuhri, Wahid Hasyim mempunyai pergaulan yang sangat luas. Bukan hanya di kalangan umat Islam dan para pemimpinya, melainkan juga di kalangan politisi dari berbagai golongan. Zuhri sering menyertai Hasyim mengikuti pertemuan dengan Bung Karno, Bung Hatta, Ahmad Subardjo, Muhammad Yamin, Sartono, Sukiman, dan Pak Dirman. Ia juga sering menyertai Hasyim ketika bertemu dengan kelompok pemuda seperti Sukarni, Chairul Saleh, BM Diah, Anwar Tjokroaminoto, dan Asa Bafaqih. Pada suatu hari Hasyim menerima tamu yang mengaku Pak Husin. Setelah "Pak Husin" berlalu, Hasyim memberitahu kepada Zuhri bahwa Pak Husin itu sebenarnya Tan Malaka. Peristiwa tersebut terjadi pada tahun 1944-1945 di Jakarta. Wahid Hasyim pada waktu itu memainkan peran sentral perjuangan umat Islam dalam kemerdekaan. Beliau membina kelompok pemuda, antara lain Harsono Cokroaminoto, Amir Fatah, Ahmad Fatoni, Asa Bafaqih, Muhammad Sjahid dan Djanamar Azam (Mustoffa-peny. 1986: 244-249).

Seperti halnya Hughes yang memetakan kehancuran sekolah tradisi Cina karena invasi sekolah Barat, jika tidak kritis, pesantren lambat laun akan mengalami proses yang demikian. Hal ini terjadi dalam kasus surau atau pesantren khas Minang di Sumatera. Surau biasanya dibangun dekat dengan sumber air. Karena itu di sekitar surau sering muncul permukiman, kegiatan dagang, pasar, juga peradaban baru. Keberadaan surau tidak lepas dari posisi kedekatannya dengan jaringan keulamaan, tarekat, hingga pasar dan perdagangan antar kota-desa-pesisir di Sumatera. Adat pun dirangkul dan dibuat berorientasi ke Mazhab Syafi'i. 
Surau Ulakan merupakan surau pertama yang berada dalam sirkuit gerakan keilmuan yang menghubungkan pesisir Sumatera Barat dan pesisir Aceh. Relasi ini menjadi pusat pengembangan Islam dengan adat sebagai mitranya, sehingga terjadi perpaduan serasi di antara keduanya. Dalam relasi ini selain ada usaha ekstensifikasi, yakni perluasan penyiaran Islam di tengah masyarakat adat, juga ada upaya intensifikasi, yaitu pendalaman berbagai jenis ilmu keislaman dalam surau, sehingga keislaman masyarakat benar-benar mendalam, sesuai dengan ajaran kitab dan para ulama salaf.

Jaringan ke pedalaman, sejak abad ke-18 dilakukan oleh surau yang menekuni gerakan tarekat. Ada tiga tarekat besar di masa itu: Naqsyabandiyah, Syathariyah dan Qâdiriyah. Kehadiran Surau Batuhampar di pedalaman Minangkabau dimungkinkan berkat jaringan surau tarekat ini. Jaringan surau juga menghubungkan diri dengan jaringan pasar dan ekonomi strategis di Minang, seperti jaringan desa pertanian subur dan makmur, jaringan desa pertambangan yang kaya, juga jaringan desa yang terletak di persimpangan rute dagang. Surau Ulakan misalnya, menjadi penggerak jaringan tarekat Syathariyah di jaringan desadesa dagang dari Padang Panjang, Kota Lawas, hingga ke jaringan persawahan kaya di Agam Selatan, terutama di Kota Tua. Sementara surau yang mengajarkan tarekat Naqsyabandiyah muncul di sekitar jaringan tambang emas Talawi di Tanah Datar. Surau Silungkang, muncul di jaringan desa-desa pertambangan batu bara yang kaya.

Jaringan surau tarekat ini kemudian membawa warna baru ke dalam peta geografis penguasaan ilmu-ilmu keagamaan sejak abad ke-18. Jaringan Surau Ulakan dengan tarekat Syathariyah-nya sangat kuat mendalami ilmu-ilmu fiqih. Kitab Minhâju 't-Thâlibîn karya Imam Nawawi, Kitab Tubfat al-Mubtâj karya Ibnu Hajar al-Haitami, hingga karya fiqih Syekh Abdurrauf Singkel, adalah bacaan favorit "urang siak" di surau ini. Surau-surau di Kamang lebih fokus pada ilmu alat, seperti nabwu, sharaf dan qawâid al-lughah (seluk beluk tata bahasa dan leksikografi Arab). Di Kota Gadang suraunya terkenal dengan penguasaan ilmu manthiq dan ilmu ma'âni, berkat Tuanku di Tanah Rao yang baru pulang dari Mekah dan menurunkannya kepada Tuanku Nan Katjik. Surau di Kota Tua terkenal dengan ilmu tafsirnya.

Setelah kehadiran Tuanku Nan Tuo, perkembangan tradisi keilmuan surau Minangkabau semakin canggih. Berbagai disiplin keilmuan yang terpisah antara satu surau dengan surau lainnya, mulai diintegrasikan ke dalam Surau Koto Tuo Empat Angkat, Agam, yang didirikan oleh Tuanku Syekh Nan Tuo. Di penghujung abad 18, surau ini menjadi terkenal, dan banyak didatangi oleh para santri (urang siak) dari berbagai daerah.

Kemunculan kelompok Padri di Minangkabau pada abad ke-19 menghambat laju perkembangan surau dan itu berjalan bersamaan dengan masuknya penjajahan Belanda di daerah pedalaman. Kompeni berkepentingan menguasai sumber ekonomi strategis Minangkabau. Keributan yang ditimbulkan oleh Kaum Padri dengan kaum adat dan komunitas surau memunculkan masalah 
keamanan internal, terutama keamanan bisnis kolonial. Maka, ada alasan untuk menindak Kaum Padri dan menjinakkan kaum adat dan komunitas surau untuk melepaskan aset-aset strategis ekonomi mereka.

Perang Padri dan ekspansi kolonialisme akhirnya memotong jaringan keulamaan, dagang, dan pusat ekonomi strategis yang selama ini dinikmati oleh komunitas surau. Jaringan keulamaan dan tarekat diceraiberaikan oleh kelompok puritan Padri dan oleh pelanjutnya, kelompok Wababi-reformis. Sementara, jaringan dagang dan ekonomi strategis diambil-alih Kompeni. Keuntungannya dibawa ke Belanda. Perlawanan terhadap kelompok puritan dan pemerintah kolonial sejak awal abad ke-20 pun terpencar, meski tetap digerakan oleh komunitas surau dan tarekat. Dalam Pemberontakan Kamang tahun 1908, komunitas surau mulai mengajarkan kemandirian dengan bertani, dan meminta tanah penduduk untuk tidak dijual atau disewakan kepada orang berkulit putih. Namun, akibat gerakan modernisasi dan pembaruan Islam yang dilancarkan sejak masa Padri hingga kemunculan Kaum Muda di tahun 1920-an ternyata tidak membawa orang Minang untuk menguasai kembali sumber dan jaringan ekonomi strategis mereka. Akhirnya, mereka lebih memilih merantau, dan meninggalkan surau kemudian bergumul dengan perkembangan zaman.

\section{SIMPULAN}

Upaya kembali ke pesantren pada dasarnya merupakan langkah, tahapan, dan program untuk mengangkat kembali kondisi bangsa ini yang sedang terpuruk. Upaya tersebut dapat dilakukan dengan cara: 1) menumbuhkan kembali rasa percaya diri orang pesantren karena mereka memiliki sejarah yang tertulis dengan tinta emas. Bangsa ini mempunyai hutang historis kepada pesantren karena berkat amal salehnya dalam menjaga dan mengembangkan kelangsungan hidup bangsa ini, baik masa lalu, masa kini maupun di masa mendatang. Orang pesantren tidak pernah minta imbalan untuk amal salehnya tersebut. Mereka juga tidak meminta penghargaan atau jasa, misalnya meminta menjadi pahlawan nasional atau ngotot dimakamkan di Taman Makam Pahlawan. Mereka tidak perlu nama dan tidak perlu untuk tampil dan ditampilkan.

Hal yang penting bagi mereka adalah tampilannya. Orang pesantren mempunyai modal kuat untuk menopang dan mengawal bangsa ini karena keikhlasan, kesederhanaan, dan ikatan komunitas-kebangsaannya tetap terpelihara dengan baik. Sikap percaya diri itu dimulai dari bagaimana orang pesantren menggali kembali modal kultural yang melahirkan sikap sosial dan amal saleh nasionalis tersebut; 2) mengupayakan bagaimana orang pesantren mengisi kembali serta memperkukuh pilar kebangsaan kita yakni: Pancasila, UUD 1945, NKRI, dan Bhinneka Tunggal Ika. Jika para kiai protes sejumlah pihak yang ingin melakukan sekularisasi terhadap Pancasila atau pada puritanisasi pilar bangsa, dengan ide dan gagasan politik dari Timur Tengah, seperti khilafah, negara Islam, hingga Islamisasi Undang-undang, maka itu semua merupakan 
wujud perhatian orang pesantren terhadap masa depan bangsa ini dalam mengisi pemaknaan dan pengukuhan keempat pilar keindonesiaan tersebut; 3) mengisi substansi pendidikan Pancasila dengan sesuatu yang khas Abl as-sunnab wal jamaah (Aswaja), Islam Nusantara, dan juga berwatak kebangsaan sebelum "direbut" oleh kelompok liberal atau fundamentalis; 4) menggalakan kembali program kaderisasi anak pesantren untuk segenap wilayah perhatian bangsa ini ke masa depan, politik, ekonomi, kebudayaan, intelektualitas, dan hukum. Ini harus cepat dilakukan sebelum mereka terlanjur jauh dikader oleh orang lain atau bangsa lain yang misinya bertentangan dengan karakter keislaman Nusantara dan menyimpang dari akar kebangsaan kita; 5) melakukan koordinasi dan konsolidasi di antara berbagai unsur Pesantren Aswaja di Nusantara. Perlu juga dilakukan penggalangan jaringan komunitas Nusantara berbasis kesamaan ideologi nasionalis-kebangsaan dan tidak ada pertentangan/dikotomi antara yang nasionalisme "religius" dan nasionalisme "sekuler"; 6) menempatkan kembali posisi pesantren sebagai wadah "barakât al-ulama fî̀ ishlâhil ummab" yang merupakan kelanjutan dari konsep tentang ulama sebagai "fâqibun fî mashâlibi \%khalq" (paham benar akan kemaslahatan umat manusia). Sebutan tersebut merupakan karakter ulama sebagai subyek (fâil) dan predikatnya "barakat ishlâhil ummah" yakni misi dan tanggung jawab yang diemban oleh ulama, yaitu keagamaan, keumatan dan kebangsaan. Ada mas'ûliyyah, yakni tanggung jawab dalam membina, membimbing, dan mengarahkan umat dan bangsa, baik yang menyangkut keagamaan (diniyyah) maupun aspek kemasyarakatan (ijtimâ'iyyah). Ada "mas'ûliyyat ar-ri'âyah" yakni, tanggung jawab dalam memelihara dan membimbing umat dan bangsa. Ada "mas'ûliyyat al-qiyâdah wal imâmah" yaitu tanggung jawab dalam memimpin serta ada mas'ûliyyat al-ishlâh, yaitu tanggung jawab dalam perbaikan dan mereformasi.

Dalam makna ishlâh ini, kembali ke pesantren merupakan upaya reformasi total terhadap segenap agenda bangsa yang sudah melenceng ? jauh dari cita-cita kebangsaan. Hal ini diungkap oleh Hadhratussyekh K.H. Hasyim Asy'ari, "Ayyuba 'l-ulama, tanzhuru al-ummat al-islâmiyat al-indûnîsiyah ilaykum litarâ mâdza ta'malîna fî ishlâhi ahwâlihim ad-diniyyah wa '-ijtimâ'iyyah". Wahai para ulama, bangsa Indonesia sedang memperhatikan pada kalian apa yang sedang kalian perbuat untuk umat dan bangsa ini dalam upaya melakukan perbaikan, baik menyangkut keagamaan maupun dalam kemasyarakatan. Wallahu a'lam bishshawab.

\section{DAFTAR PUSTAKA}

Alfian, Teuku Ibrahim, dkk. (editor). 1992. Dari Babad dan Hikayat hingga Sejarah Kritis. Yogyakarta: Gadjah Mada University Press.

Anhar, Ratnawati. 2007. Pablawan Nasional Supriyadi. Jakarta: Balai Pustaka.

Antlöv, Hans and Tønneson, Stein (editor).1995. Imperial Policy and South East Asian Nationalism. Chippenham: Curzon.

Behrend, T.E. 1995. "Serat Jatiswara, Struktur dan Perubahan dalam Puisi Jawa 1600-1930” (terj. Achdiati Ikram, Jakarta: INIS. 
Benedict R. O'G. Anderson. 2006. Java in a Time of Revolution: Occupation and Resistance, 1944-1946. Jakarta \& Singapore: Equinox Publishing.

Bonneff, Marcel et. al. 1983. Citra Masyarakat Indonesia. Jakarta: Sinar Harapan.

Carey, Peter. 1986. 'Waiting for the 'Just King': The Agrarian World of South-

Central Java from Giyanti (1755) to the Java War (1825-30)". Modern Asian

Studies, vol. 20, no. 1.

Dewantara, Ki Hadjar. 1952. Taman Siswa 30 Tabun 1922-1952. Yogyakarta: Madjelis Luhur Taman Siswa.

Dewantara, Ki Hadjar. 1962. Karja Ki Hadjar Dewantara Bagian ke-II A: Kebudayaan). Yogyakarta: Madjelis Luhur Persatuan Taman Siswa.

Djajadiningrat, Achmad, P. A. 1996 (1936). Memoar Pangeran Aria Achmad Djajadiningrat. Jakarta: Paguyuban Keturunan P.A. Achmad Djajadiningrat.

Federspiel, Howard M. 1977. "Islam and Nationalism". Indonesia. no. 24, October.

------, 2004, Labirin Ideologi Muslim: Pencarian dan Pergulatan Persis di Era Kemunculan Negara Indonesia (terj, Ruslani dan Kurniawan Abdullah). Jakarta: Serambi.

Florida, Nancy, K. 1995. Writing the Past, Inscribing the Future: History as Prophecy in Colonial Java. Durham dan London: Duke University Press.

Frederick, William H. 1989. Pandangan dan Gejolak: Masyarakat Kota dan Labirnya Revolusi Indonesia (Surabaya 1926-1946). terj. Hermawan Sulistiyo, Jakarta: Gramedia dan Yayasan Karti Sarana.

Hasjmy, A. 1997. Ulama Aceh: Mujabid Pejuang Kemerdekaan dan Pembangun Tamaddun Bangsa. Jakarta: Bulan Bintang.

Hefner, Robert W. 1987. "Islamizing Java?: Religion and Politics in Rural East Java". The Journal of Asian Studies. vol. 46, No. 3, Agustus.

Hughes, E. R. 1937. The Invasion of Cina by The Western World. London: Adam and Charles Black.

Joesoef, Daoed. 2003. Emak. Jakarta: Aksara Karunia.

Kahin, Audrey K., (editor). 1985. Regional Dynamics of The Indonesian Revolution: Unity From Diversity, Honolulu: University of Hawaii Press.

Kartodirdjo, Sartono, dkk. 1977. Sejarah Nasional Indonesia. edisi 2, Jakarta: Balai Pustaka dan Departemen Pendidikan dan Kebudayaan.

Koto, Naskhar. 1986. "Masa Kecil Sukarni", dalam Sumono Mustoffa (penyunting), Sukarni dalam Kenangan Teman-temannya. Jakarta: Sinar Harapan.

Laffan, Michael, Francis Islamic. 2003. Nationbood and Colonial Indonesia: The Umma below the Winds. London dan New York: Routledge Curzon.

Lubis, Nina Herlina. 1998. Kebidupan Kaum Menak Priangan. 1800-1942, Bandung: Pusat Informasi Kebudayaan Sunda.

Lubis, Nina Herlina. 2004. Banten dalam Pergumulan Sejarab: Sultan, Ulama, Jawara. Jakarta: LP3ES. 
Lucas, Anton. 1989. Peristiwa Tiga Daerah: Revolusi dalam Revolusi. Jakarta: Grafitipres.

Mihardja, K. Achdiat (pengumpul). 1986. Polemik Kebudayaan. cet. 4, Jakarta: Pustaka Jaya.

Mustoffa, Sumono (penyunting), Sukarni dalam Kenangan Teman-temannya (Jakarta: Sinar Harapan, 1986), hal. 244-249.

Navis, A.,A. 1989. Pasang Surut Pengusaha Pejuang: Otobiografi Hasjim Ning.

Oetomo, Dédé. 1987. "Serat Ang Dok: A Confucian Treatise in Javanese". Archipel vol. 34.

Pardi, et. al. 1995. Sastra Jawa: Periode Akhir Abad XIX-Tabun 1920. Jakarta: Departemen Pendidikan dan Kebudayaan.

Poeze, Harry A. 2008. Tan Malaka, Gerakan Kiri dan Revolusi Indonesia: jilid 1 Agustus 1945-Maret 1946. terj. Hersri Setiawan, Jakarta: Yayasan Obor Indonesia.

Pranowo, Bambang M. 2009. Memahami Islam Jawa. Jakarta: Alvabet \& INSEP.

Salmon, Claudine. 1971. "Le Sjair de l'Association chinoise' de Batavia (1905)". Archipel vol. 2.

Soeharto, R. 1982. Saksi Sejarah: Mengikuti Perjuangan Dwi-Tunggal. Jakarta: Gunung Agung.

Sol Tas. 1969. "Souvenirs of Sjahrir". Indonesia. No. 8, October.

Tanpa Nama. 1985. Sawerigading. Jakarta: Departemen Pendidikan dan Kebudayaan.

Tim Babcock. 1981. "Muslim Minahasans with Roots in Java: The People of Kampung Jawa Tondano". Indonesia, No. 32.

Tim Penulis IAIN Ar-Raniry. 2004. Ensiklopedi Pemikiran Ulama Aceh, Banda Aceh: Ar-Raniry Press.

Tjokroaminoto, Harsono. 2000. "Tekad Menjadi Bangsa Merdeka”, dalam Bunga Rampai Perjuangan dan Pengorbanan. Jakarta: Markas Besar Legiun Veteran RI, jilid 2.

Tsuchiya, Kenji. 1992. Demokrasi dan Kepemimpinan: Kebangkitan Gerakan Taman Siswa (terj. H.B. Jassin). Jakarta: Balai Pustaka.

Van der Veur, Paul W (ed.). 1984. Kenang-kenangan Dokter Soetomo. Jakarta: Sinar Harapan.

Van der Veur, Paul W. 1952. Taman Siswa 30 Tabun 1922-1952. Yogyakarta: Madjelis Luhur Taman Siswa.

Wijaya, Putu. 1999. Bor: Esai-esai Budaya. Yogyakarta: Bentang.

Zuhri, K.H., Saifuddin. 1987. Berangkat Dari Pesantren. Jakarta: Gunung Agung. , 1987. Berangkat dari Pesantren. Jakarta: Gunung Agung.

------, 2001/1974. Guruku Orangdari Pesantren. Yogyakarta: LKis dan Yayasan Saifuddin Zuhri. 